\title{
Evaluasi Kualitas Produk Dadih Dalam Bentuk Bubuk Yang Dikeringkan Dengan Sinar Matahari Dan Oven
}

\author{
L. Ibrahim \\ Fakultas Peternakan Universitas Andalas, Limau Manis, Padang
}

\begin{abstract}
The research was conducted to compare the quality of curd in powder processed by using natural (sun) and oven drying. Results showed drying processes did not give significant effect on the quality of curd products. Curd powder produced by using natural drying had acidity of $1.50 \%, \mathrm{pH} 4.02$, total number of bacteria of 2 $x 10^{4}$ colony /gram, water content of $7.02 \%$ and protein of $14.4 \%$, while that of dried by oven had acidity $1.46 \%, \mathrm{pH} 4.04$, total bacteria $1.5 \times 10^{3}$ colony/ gram, water content $6.8 \%$ and protein $14.02 \%$.
\end{abstract}

$\underline{\text { Key words: }}$ curd powder, acidity, $\mathrm{pH}$, water and protein content.

\section{Pendahuluan}

Dadih merupakan makanan tradisional, adat, kesenangan dan sudah dikonsumsi oleh masyarakat Minang diduga sudah lebih dari ratusan tahun yang lalu. Menurut sejarahnya sejak dilakukan pemerahan kerbau, peternak kerbau telah mengolah susu kerbau menjadi dadih. Dadih dibuat dengan cara yang sangat sederhana. Susu kerbau yang sudah diperah dimasukkan ke dalam ruas tabung bambu, bagian atas ditutup daun pisang segar atau kering dan disimpan pada suhu kamar. Dikonsumsi setelah diperam selama dua hari atau lebih.

Sebagai makanan adat dadih disuguhkan pada acara pernikahan, peresmian perkawinan, pemberian gelar Datuk dan lain - lain. Sebagai makanan kesenangan dadih dijual di pasar desa, kecamatan dan kota. Di warung dan restoran dadih dihidangkan dalam bentuk makanan yang disebut emping dadih. Emping dadih ialah dadih yang dimakan bersama emping ketan yang disiram air mendidih, ditambah dengan larutan gula aren dan kelapa parut. Penduduk desa terutama peternak yang memerah kerbau menjadikan dadih sebagai lauk - pauk untuk teman nasi.

Bahan baku dari dadih adalah susu kerbau mentah. Survai lapangan yang dilakukan penulis memberikan informasi bahwa $96 \%$ dari susu kerbau mentah yang diperoleh peternak dibuat dadih (Ibrahim, 2002). Susu kerbau mempunyai nilai gizi lebih tinggi, dibandingkan susu sapi terutama dalam hal kandungan lemak, protein dan bahan kering.

Susu sudah dikenal sebagai bahan pangan yang tinggi daya cernanya. Kerbau sebagai ternak yang di budidayakan memberi sumbangan besar bagi kehidupan manusia, diantaranya digunakan untuk sumber tenaga, daging, kulit, susu, pupuk dan mempunyai arti sosial bagi penduduk setempat dan pemilik. Keuntungan bagi petani peternak yang memeliharanya dapat meningkatkan kesejahteraannya, diantaranya tambahan penghasilan, perbaikan gizi keluarga, bantuan tenaga dalam memperoleh hasil taninya dan social standing. Biaya yang dikeluarkan untuk 
membudidayakan ternak ini tidak besar, umumnya di Indonesia hanya memberikan rumput atau membiarkan kerbau merumput di lapangan. Yang menjadi kendala sekarang adalah lapangan tempat kerbau merumput atau peternak mengaritkan rumput semakin berkurang,

Sumbangan protein yang berasal dari susu kerbau kepada penduduk Sumatera Barat lebih basar dari sumbangan protein yang berasal dari susu sapi. Perbandingan produksi susu sapi dengan susu kerbau pada tahun 2003, adalah $833.250 \mathrm{~kg}$ banding $2.947 .700 \mathrm{~kg}$, tahun sebelumnya juga demikian produki susu sapi di Sumatera Barat lebih rendah jika dibandingkan dengan produksi susu kerbau (Anonimus, 2003).

Uraian yang telah dijelaskan memberikan informasi bahwa dadih merupakan makanan tradisional yang disukai, bergizi tinggi, mudah dimanfaatkan tubuh, menambah pendapatan dan perbaikan gizi keluarga peternak yang mengkonsumsi susu dan dadih. Susu kerbau juga merupakan penyumbang protein susu yang terbanyak dibanding ternak perah lain yang dipelihara di Sumatera Barat. Sugita dan Lusy (1998) melaporkan kisaran protein dadih adalah 7,51 - 8,84\% Dewasa ini yang menjadi masalah besar dalam mengkonsumsi susu kerbau dan dadih adalah tidak disukainya oleh kalangan muda dan anak - anak, sehingga masa depan dari produksi susu kerbau dan dadih menjadi suram. Kurang disukainya dadih ini oleh generasi muda adalah karena aroma dan rasanya yang kecut. Begitu juga tampilannya di dalam tabung bambu saat dipasarkan.

Diversifikasi dari produksi ini perlu diusahakan, diantaranya dengan mengeringkan dadih ini menjadi bubuk dadih, akan tetapi yang perlu diperhatikan adalah nilai manfaatnya jangan sampai hilang.

Keunggulan dadih/susu fermentasi dibanding dengan susu segar/ pasteurisasi diantaranya adalah : lebih mudah dicerna, mengandung asam laktat dan bakteri asam laktat, serta protein yang mudah dicerna. Dadih atau susu fermentasi padat dengan gizi dan mengandung senyawa yang dapat mempertahankan dan memperbaiki kesehatan manusia, hal ini telah banyak dilaporkan oleh para peneliti.

Bubuk dadih yang telah diproses dengan cara pengeringan dapat direkayasa menjadi produk susu yang disukai oleh semua umur, nilai manfaatnya dapat dipertahankan dan dapat dipasarkan secara luas misal dibuat tablet kunyah dadih dengan berbagai aroma dan rasa.

Dadih merupakan makanan tradisional Sumatera Barat. Dari dulu sampai sekarang dadih ini tetap diproduksi oleh peternak yang memerah kerbau. Sebagai makanan adat dan kesenangan dadih selalu dibutuhkan masyarakat Minang.

Sebagai makanan yang telah dapat diterima masyarakat, dadih memiliki masalah dalam memproduksi dan memanfaatkannya misalnya adalah (1) dadih dibuat, disimpan dan dipasarkan dalam tabung bambu. (2) dadih dibuat dari susu mentah tanpa melalui pasteurisasi dan (3) dadih umur 7 hari masih dikonsumsi penduduk, walaupun sudah ditumbuhi kapang.

Penelitian dilakukan dengan tujuan untuk mempelajari pengaruh proses pengeringan dengan sinar matahari dan oven terhadap kualitas produk dadih dalam bentuk bubuk. 


\section{MATERI DAN METODE}

\section{Pembuatan Dadih}

Susu kerbau mentah yang sudah diperoleh dari peternak di masukan ke dalam 18 tabung bambu, masing masingnya sejumlah $150 \mathrm{ml} /$ tabung. Tabung bambu yang digunakan mempunyai ukuran panjang ruas yang dapat diisi susu kerbau $10 \mathrm{~cm}$, dibawah ruas tersebut terdapat buku yang tebalnya sekitar $0,5 \mathrm{~cm}$, dibawah buku ada ruang kosong yang panjangnya $7 \mathrm{~cm}$ dan diameter ruang ruas bambu sekitar $5-5,5 \mathrm{~cm}$. Seterusnya tabung bambu ditutup dengan daun pisang yang sudah dilayukan kemudian diikat dengan karet gelang dan disimpan/diperam pada suhu ruang /kamar selama 2 x 24 jam. Setelah 2 hari susu kerbau di diperam dalam tabung bambu susu telah berubah menjadi dadih yang terdiri dari bagian yang menggumpal yang disebut curd dan bagian cair yang disebut whey.

\section{Proses Pengeringan}

Isi tabung selanjutnya dikeluarkan dan diaduk atau dihomogenkan. Sebanyak $50 \mathrm{~g}$ dimasukkan kedalam kantong plastik polyetilene dengan ketebalan 0,04 mm, permukaan kantong plastik dilobangi dengan jarum suntik dan dadih di dalamnya ditipiskan agar air mudah mengalir dan menguap melalui lobang pada plastik. Sembilan kantong yang berisi sampel dikeringkan dengan sinar matahari dan sembilan kantong lainnya dikeringkan dalam oven. Setelah kering seperti bubuk dilakukan analisis variabel yang telah ditetapkan.

\section{Pengukuran Parameter}

Keasaman ditentukan dengan cara titrasi, $\mathrm{pH}$ ditentukan dengan $\mathrm{pH}$ meter, total bakteri ditentukan dengan cara PCA, kadar air ditentukan dengan analisis proksimat dan kadar protein ditentukan dengan metode Kjeldahl.

\section{HASIL DAN PEMBAHASAN}

Hasil penelitian keasaman, $\mathrm{pH}$, total bakteri dan kandungan air serta protein dari bubuk dadih yang dikeringkan dengan sinar matahari dan oven dapat dilihat pada Tabel 1 dan Tabel 2

Pada Tabel 1 dan Tabel 2 dapat dibaca bahwa kadar asam dari bubuk dadih yang dibuat dengan cara pengeringan sinar matahari dan oven adalah $1,5 \%$ dan 1,46\%. Ibrahim (2002) menemukan kadar asam dari susu kerbau mentah dan dadih adalah 0,25 $\%$ dan 1,01 \%. Kadar asam dari bubuk dadih yang dihasilkan cukup tinggi. Hal ini menunjukkan bahwa bubuk dadih yang dihasilkan cukup punya potensi untuk menahan atau mematikan bakteri patogen yang berada dilingkungannya.

Hasil pengukuran $\mathrm{pH}$ dari bubuk dadih yang dikeringkan dengan sinar matahari dan oven adalah 4,02 dan 4,04. Ibrahim (2002) melaporkan bahwa $\mathrm{pH}$ dadih pada lama pemeraman 48 jam adalah 4,67. Rendahnya $\mathrm{pH}$ bubuk dadih yang dihasilkan diasumsikan ketika dadih dikeringkan pembentukkan asam terus berlangsung.

Di dalam Tabel 1 dan Tabel 2 dicantumkan kandungan bakteri dari bubuk dadih yang diproses dengan cara pengeringan sinar matahari dan oven seperti berikut 20.000 koloni / gram dan 1500 koloni/gram. Data menunjukkan bahwa jumlah bakteri lebih banyak ditemukan pada bubuk dadih yang dibuat dengan cara pengeringan oven, kejadian ini disebabkan pengaruh suhu, oven suhunya tetap stabil dalam waktu yang lama, akibatnya dapat menekan pertumbuhan bakteri. 
Tabel 1. Kadar Asam, pH, Total Bakteri, Kandungan Air dan Protein Bubuk Dadih yang Dikeringkan dengan Sinar Matahari.

\begin{tabular}{cccccc}
\hline $\begin{array}{c}\text { Nomor } \\
\text { Sample }\end{array}$ & $\begin{array}{c}\text { Kadar Asam } \\
(\%)\end{array}$ & $\mathrm{pH}$ & $\begin{array}{c}\text { Total Bakteri } \\
\text { (coloni/gram) }\end{array}$ & $\begin{array}{c}\text { Air } \\
(\%)\end{array}$ & $\begin{array}{c}\text { Protein } \\
(\boldsymbol{\%})\end{array}$ \\
\hline 1 & 1,61 & 3,99 & 18.000 & 7,00 & $\mathbf{1 4 , 6}$ \\
2 & 1,50 & 4,02 & 21.000 & 7,02 & $\mathbf{1 4 , 4}$ \\
3 & 1,66 & 3,96 & 22.000 & 7,04 & $\mathbf{1 4 , 2}$ \\
4 & 1,33 & 4,07 & 21.000 & 7,03 & $\mathbf{1 4 , 3}$ \\
5 & 1,40 & 4,05 & 21.000 & 7,01 & $\mathbf{1 4 , 5}$ \\
6 & 1,50 & 4,02 & 18.000 & 7,02 & $\mathbf{1 4 , 4}$ \\
7 & 1,50 & 4,03 & 22.000 & 7,02 & $\mathbf{1 4 , 4}$ \\
8 & 1,39 & 4,05 & 20.000 & 7,03 & $\mathbf{1 4 , 3}$ \\
9 & 1,61 & 3,99 & 18.000 & 7,01 & $\mathbf{1 4 , 5}$ \\
Mean & 1,50 & 4,02 & 20.000 atau $2 \times 10^{4}$ & 7,02 & $\mathbf{1 4 , 4}$ \\
SD & $\mathbf{0 , 1 1 3}$ & $\mathbf{0 , 1 0 6}$ & & $\mathbf{0 , 0 1 3}$ & $\mathbf{0 , 0 1 2}$ \\
\hline
\end{tabular}

Tabel 2. Kadar Asam, pH, Total Bakteri, Kandungan Air dan Protein Bubuk Dadih yang Dikeringkan dengan Oven

\begin{tabular}{cccccc}
\hline $\begin{array}{c}\text { Nomor } \\
\text { Sample }\end{array}$ & $\begin{array}{c}\text { Kadar Asam } \\
(\%)\end{array}$ & $\mathrm{pH}$ & $\begin{array}{c}\text { Total Bakteri } \\
\text { (coloni/gram) }\end{array}$ & $\begin{array}{c}\text { Air } \\
(\%)\end{array}$ & $\begin{array}{c}\text { Protein } \\
(\%)\end{array}$ \\
\hline 1 & 1,47 & 4,03 & 13,00 & 6,85 & $\mathbf{1 4 , 0 1}$ \\
2 & 1,46 & 4,04 & 16,00 & 6,80 & $\mathbf{1 4 , 0 2}$ \\
3 & 1,50 & 4,01 & 17,00 & 7,00 & $\mathbf{1 4 , 0 3}$ \\
4 & 1,44 & 4,05 & 14,00 & 6,70 & $\mathbf{1 4 , 0 2}$ \\
5 & 1,45 & 4,05 & 15,00 & 6,75 & $\mathbf{1 4 , 0 2}$ \\
6 & 1,44 & 4,06 & 16,00 & 6.70 & $\mathbf{1 4 , 0 3}$ \\
7 & 1,46 & 4,04 & 12,00 & 6,80 & $\mathbf{1 4 , 0 2}$ \\
8 & 1,45 & 4,05 & 16,00 & 6,75 & $\mathbf{1 4 , 0 2}$ \\
9 & 1,47 & 4,03 & 17,00 & 6,85 & $\mathbf{1 4 , 0 1}$ \\
Mean & 1,5 & 4,02 & 1.500 atau $1,5 \times 10^{3}$ & 7,02 & $\mathbf{1 4 , 0 2}$ \\
SD & $\mathbf{0 , 0 1 2}$ & $\mathbf{0 , 0 0 1}$ & & $\mathbf{0 , 0 1 3}$ & $\mathbf{0 , 0 1 2}$ \\
\hline
\end{tabular}

Kadar air dari bubuk dadih yang dibuat dengan cara pengeringan sinar matahari dan oven adalah $7,02 \%$ dan $6,8 \%$. Kadar air dari bubuk dadih yang diproses di dalam oven adalah rendah, hal ini disebabkan suhu oven tetap stabil dan menghasilkan panas yang merata dan mengakibatkan penguapan air dadih berlansung terus menerus sampai dadih menjadi bubuk.

Kandungan protein bubuk dadih yang dibuat dengan cara pengeringan sinar matahari dan oven adalah $14,4 \%$ dan 14,02 \% (tercantum pada Tabel 1 dan 2). Perbedaan kandungan protein bubuk dadih yang dibuat dengan cara pengeringan sinar matahari dan oven relatif tidak besar.

\section{KESIMPULAN}

Dari hasil penelitian dapat disimpulkan bahwa proses pengeringan yang berbeda tidak berpengaruh terhadap kualitas produk dadih dalam 
bentuk bubuk. Dadih yang dikeringkan baik dengan cara menggunakan sinar matahari maupun oven dapat menghasilkan bubuk dadih dengan keasaman yang memadai dan masih mengandung bakteri asam laktat.

\section{DAFTAR PUSTAKA}

Anonimus. 2003. Laporan Tahunan

Dinas Peternakan Sumatera

Barat. Dinas Peternakan Propinsi Sumatera Barat. Padang.
Ibrahim, L. 2002. Kajian Dadih Susu Kerbau Lumpur di Sumatera Barat. Disertasi. Universitas Gadjah Mada, Yogyakarta.

Sugitha, I. M. \& Lucy A. A. 1998. Daya cerna dadih yang dibuat dengan penambahan starter streptoccocus dalam tabung plastik. Jurnal Peternakan dan lingkungan. Vol. 4. No. 3.

\section{Alamat Korespondensi: Dr. Lukman Ibrahim Jurusan Poduksi Ternak Fakultas Peternakan Universitas Andalas, Limau Manis Padang.}

Artikel diterima: 27 Mei 2006, disetujui: 31 Mei 2006. 